\title{
KEBIJAKAN PROGRAM PENINGKATAN KESEJAHTERAAN GURU DALAM RANGKA MENINGKATKAN MUTU PENDIDIKAN
}

\author{
Edy Putra Kelana \\ Dosen Program Studi Administrasi Publik Fakultas Ilmu Sosial dan Ilmu Politik Universitas Almuslim \\ Email: kelana.edyputra@yahoo.com
}

Diterima 25 Mei 2021/Disetujui 5 Juni 2021

\begin{abstract}
ABSTRAK
Kajian pustaka ini bertujuan untuk mengetahui lebih jauh tentang kebijakan program peningkatan kesejahteraan guru dalam rangka meningkatkan mutu pendidikan. Berdasarkan pembahasan kajian pustaka ini diperoleh bahwa inti dari mutu pendidikan terletak pada apa yang terjadi dan berlangsung di ruang kelas. Hal ini dibuktikan dengan beberapa penelitian pendidikan yaitu salah satu faktor dominan yang menentukan tingkat keberhasilan anak didik dalam melakukan proses transformasi ilmu pengetahuan dan teknologi adalah kompetensi guru dalam melaksanakan proses pembelajaran di kelas. Oleh karena itu, masalah guru merupakan topik yang tidak habis dibahas dalam berbagai seminar, diskusi dan workshop untuk mencari berbagai alternatif pemecahan terhadap berbagai persoalan yang dihadapi guru dalam menjalankan tugasnya sebagai pengajar dan pendidik di lingkungan sekolah. Adapun masalah guru berkisar pada persoalan kurang memadainya kualifikasi akademik dan kompetensi guru, kurangnya tingkat kesejahteraan guru, distribusi guru dan kurangnya penghargaan masyarakat terhadap profesi guru. Yang paling penting harus dilakukan adalah menyiapkan sosok guru masa depan yang sesuai tuntutan reformasi pendidikan dan perkembangan ilmu pengetahuan dan teknologi.
\end{abstract}

Kata kunci: kebijakan, kesejahteraan guru, mutu pendidikan

\section{PENDAHULUAN}

Memperhatikan perkembangan pendidikan di dunia internasional, sudah tiba saatnya pendidikan di Indonesia segera bangkit mempersiapkan generasi ke depan untuk bersaing dengan negara lain dalam membangun ekonomi Indonesia di masa akan datang. Peran pendidikan dalam pembangunan ekonomi sangat penting mengingat pelaku-pelaku ekonomi memerlukan sumber daya manusia yang berkualitas. Kualitas manusia yang dibutuhkan oleh bangsa Indonesia pada masa akan datang adalah yang mampu menghadapi persaingan yang semakin ketat dengan bangsa lain di dunia. Kualitas manusia Indonesia tersebut dihasilkan melalui penyelenggaraan pendidikan yang bermutu. Untuk itu, pembangunan pendidikan yang bermutu merupakan syarat mutlak dalam mempersiapkan sumber daya manusia yang berkualitas sehingga terwujudnya kehidupan bangsa yang maju dan sejahtera.

Berbicara mutu pendidikan, diketahui bersama bahwa banyak faktor yang berperan dalam peningkatan mutu pendidikan. Guru merupakan salah satu faktor utama, karena pendidikan yang bermutu bergantung pada keberadaan guru yang bermutu, yakni guru yang profesional, sejahtera dan bermartabat. Maka, guru mempunyai fungsi, peran dan kedudukan yang sangat strategis. Hampir semua negara di dunia yang memiliki pendidikan bermutu mengembangkan kebijakan untuk mendorong keberadaan guru berkualitas. Salah satu kebijakan yang dikembangkan di banyak negara adalah intervensi langsung peningkatan kompetensi dan memberikan jaminan serta kesejahteraan guru yang memadai. Bangsa Indonesia mulai mengembangkan kebijakan tersebut dengan diterbitkannya UU No. 14/2005 tentang Guru dan Dosen yang merupakan reformasi guru terbesar didunia.

\section{PEMBAHASAN}

\section{Guru sebagai Tenaga Profesional}

Pasal 39 Ayat (2) UU No. 20/2003 tentang Sistem Pendidikan Nasional menyatakan bahwa pendidik merupakan tenaga profesional. Pengukuhan guru dan dosen sebagai tenaga profesional tersebut 
mempunyai visi terwujudnya penyelenggaraan pembelajaran sesuai dengan prinsip-prinsip profesionalitas untuk memenuhi hak yang sama bagi setiap warga negara dalam memperoleh pendidikan yang bermutu. Selanjutnya, UU No. 14/2005 tentang Guru dan Dosen mempertegas kedudukan guru sebagai tenaga profesional dengan segala implementasi dan konsekuensinya.

Guru sebagai tenaga profesional, seperti profesi lain misalnya dokter dan pengacara, wajib memiliki kualifikasi akademik dan kompetensi serta sehat jasmani dan rohani yang dapat dibuktikan. Kualifikasi akademik seorang guru minimal setingkat S1/D4 dibuktikan dengan ijazah dari perguruan tinggi. Kompetensi guru meliputi kompetensi pedagogik, profesional, sosial dan kepribadian dibuktikan dengan sertifikat pendidik yang diperoleh melalui suatu proses penilaian kompetensi.

Adapun prinsip profesi guru sebagai pekerja profesional sesuai Undang-Undang adalah: 1) memiliki bakat, minat, panggilan jiwa dan idealisme; 2) memiliki komitmen untuk meningkatkan mutu pendidikan, keimanan, ketakwaan dan akhlak mulia; 3) memiliki kualifikasi akademik dan latar belakang pendidikan sesuai dengan bidang tugas; 4) memiliki kompetensi yang diperlukan sesuai dengan bidang tugas; 5) memiliki tanggung jawab atas pelaksanaan tugas keprofesionalan; 6) memperoleh penghasilan yang ditentukan sesuai dengan prestasi kerja; 7) memiliki kesempatan untuk mengembangkan keprofesionalan secara berkelanjutan dengan belajar sepanjang hayat; 8) memiliki jaminan perlindungan hukum dalam melaksanakan tugas keprofesionalan; dan 9) memiliki organisasi profesi yang mempunyai kewenangan mengatur hal-hal berkaitan dengan tugas keprofesionalan guru.

\section{Kesejahteraan Guru dan Mutu Pendidikan}

Beberapa pakar pendidikan berpendapat bahwa jika ingin memperbaiki mutu pendidikan, maka sejahterakan gurunya. Selain itu, beberapa hasil studi juga menyatakan bahwa tingkat kesejahteraan merupakan penentu bagi kinerja guru dalam menjalankan tugasnya. Dari beberapa studi lain yang dilakukan mengenai mutu pendidikan di berbagai negara, dilaporkan bahwa negara yang memberikan perhatian khusus pada gaji dan peningkatan kesejahteraan guru, lebih baik mutu pendidikannya.

Tingkat kesejahteraan guru sangat berpengaruh terhadap mutu pendidikan diilustrasikan bahwa rendahnya tingkat kesejahteraan guru menyebabkan rendahnya motivasi guru dalam mengajar dan kedisiplinan guru, sehingga rendahnya motivasi mengajar mempengaruhi proses pembelajaran di kelas yang cenderung berlangsung tidak efektif dan efisien. Sehingga, tidak mengherankan jika akhirnya pencapaian belajar siswa termasuk dalam Ujian Nasional menjadi di bawah target yang ditetapkan, dan berdampak pada menurunnya mutu pendidikan.

Oleh karena itu, segala keraguan terhadap guru yang dituding kurang bersungguh-sungguh atau setengah hati dalam menjalankan profesinya, dapat terjawab. Ini dibuktikan dengan kerja keras, secara sinergis bergerak bersama-sama menuju pendidikan yang semakin bermutu. Sehingga membawa bangsa ini bangkit dari keterpurukan, menjadi bangsa yang cerdas, maju, mandiri, sejahtera dan berbudaya serta memiliki daya saing dalam tataran pergaulan internasional.

\section{Kesejahteraan Guru}

Pemerintah memberikan perhatian besar terhadap kesejahteraan guru. Beberapa tunjangan guru yang diamanatkan dalam Undang-undang akan segera direalisasikan. Sudah tentu rencana kenaikan penghasilan guru tersebut harus disertai dengan peningkatan kualifikasi dan kompetensi guru.

Bagaimana kondisi gaji guru di Indonesia dibandingkan dengan gaji guru di negara lain? Adapun di negara Asia Tenggara, gaji guru di Indonesia lebih dibandingkan koleganya yang berasal dari negaranegara Indo Cina yang tergolong miskin, yaitu Cambodia, Laos dan Vietnam. Rata-rata gaji awal guru sekolah pertama di Cambodia, Laos dan Vietnam adalah US\$ 20, 12, dan 40 atau dalam rupiah sekitar 200 ribu, 120 ribu dan 400 ribu. Sehingga, jelas terlihat bahwa guru di Indonesia lebih beruntung. 
Kebijakan dalam Undang-undang Guru Dosen adalah meningkatkan kualitas kompetensi guru seiring dengan meningkatkan kesejahteraannya. Gaji guru di Indonesia jauh di bawah gaji guru Thailand dan Brunei Darussalam. Misalnya, gaji permulaan seorang guru SMP sebesar USD 300 atau sekitar 2,7 juta rupiah. Sedangkan seorang guru pemula di Brunei Darussalam dengan kualifikasi Sarjana (S1) mendapat gaji per bulan setara dengan 14 juta rupiah. Selain gaji bulanan, di Thailand dan Brunei Darussalam, setiap guru yang dipandang berhasil dalam kinerja pembelajaran akan mendapatkan bonus yaitu minimal sebesar 1 bulan gaji di akhir tahun. Namun, perlu diketahui bahwa tingkat kehidupan atau biaya hidup dan kewajiban membayar pajak di negara tersebut cukup tinggi.

Penghasilan guru sesuai ketentuan yang berlaku meliputi: 1) gaji pokok, yaitu satuan penghasilan yang ditetapkan berdasarkan pangkat, golongan dan masa kerja; 2) tunjangan yang melekat pada gaji, yaitu tambahan penghasilan sebagai komponen kesejahteraan yang ditentukan berdasarkan jumlah tanggungan keluarga; 3) tunjangan profesi, yaitu tunjangan yang diberikan kepada guru yang memiliki sertifikat pendidik sebagai penghargaan atas profesionalitasnya; 4) tunjangan khusus, yaitu tunjangan yang diberikan kepada guru sebagai kompensasi atas kesulitan hidup yang dihadapi dalam melaksanakan tugas di daerah khusus; dan 5) maslahat tambahan, yaitu tambahan kesejahteraan yang diperoleh dalam bentuk asuransi, pelayanan kesehatan, atau bentuk kesejahteraan lain yang terkait dengan tugasnya sebagai guru yang ditetapkan dengan prinsip penghargaan atas dasar prestasi.

\section{Manajemen Guru Profesional}

Fungsi dan peranan guru yang utama adalah mentransfer ilmu dan pengetahuan kepada siswa dalam proses belajar mengajar di kelas. Guru juga memiliki partisipasi yang besar dalam pengembangan mutu sekolah melalui pengembangan mutu siswa ditinjau dari aspek pengembangan daya pikir, jiwa dan raganya. Sampai dengan akhir abad 20, perhatian dunia pendidikan di Indonesia masih bertumpu pada pendidikan yang berorientasi pada kedaulatan negara yaitu menjadikan negara sebagai bangsa yang terhormat dengan mendapatkan predikat dalam kompetisi anak-anak pandai di dunia.

Prestasi yang diperoleh bangsa Indonesia di tingkat internasional cukup dibanggakan karena setiap tahun mendapat peringkat dalam kompetisi keilmuan tingkat internasional. Namun, perlu dikaji apakah prestasi ini adalah buah karya guru dalam pembelajaran di kelas. Hal ini dikarenakan guru mempunyai peran dalam memberikan dasar pengetahuan kepada siswa. Pembinaan berikutnya yaitu pra kompetisi internasional peran guru digantikan oleh dosen. Sebenarnya, keberhasilan siswa di kompetisi internasional belum mencerminkan peta kondisi pendidikan di Indonesia secara umum.

Sejalan dengan prestasi siswa yang membanggakan tersebut dan telah diproklamirkannya guru sebagai sebuah profesi, maka diperlukan manajemen guru profesional yang secara masal berdampak pada peningkatan mutu. Sebagaimana judul di atas, mengandung dua arti, pertama berarti manajemen bagi guru profesional, dan kedua dapat diartikan manajemen guru yang profesional. Keduanya memberikan kontribusi yang luar biasa dalam dunia pendidikan karena memiliki penekanan yang berbeda.

Manajemen bagi guru profesional menitikberatkan pada sekelompok guru profesional sebagai obyek. Tahapannya adalah keberadaan guru profesional dan proses pengelolaannya. Oleh karena itu, guru profesional harus ada dalam jumlah yang cukup dan diperlukan pengelolaan yang baik, sehingga sangat membantu suksesnya keterlaksanaan proses pembelajaran. Manajemen guru adalah satu kesatuan arti yang menitikberatkan pada proses pengelolaan guru yang baik dengan memperhatikan kaidah manajerial, sehingga berdampak pada pemberian layanan yang prima dalam pembelajaran.

Guru profesional telah dinyatakan dalam UU No. 14/2005 tentang Guru dan Dosen bahwa guru harus menguasai empat kompetensi, yaitu kompetensi pedagogik, kepribadian, sosial dan profesional. Kompetensi tersebut harus ditingkatkan sejalan dengan perkembangan ilmu pengetahuan dan 
teknologi. Jika dikaitkan dengan kedua pengertian tersebut, maka peningkatan kompetensi guru akan berjalan lancar dan berkesinambungan jika pengelolaan guru dilaksanakan secara profesional.

Kebijakan peningkatan kompetensi guru terjadi dalam dua level kebijakan, yaitu: 1) kebijakan peningkatan kompetensi guru di level sekolah melalui penerapan manajemen sekolah yang efektif; dan 2) kebijakan peningkatan kompetensi guru di level daerah melalui manajemen pendidikan daerah.

\section{Peningkatan Kompetensi Guru dalam Organisasi Sekolah}

Sekolah adalah organisasi yang didalamnya terdiri dari orang yang mengurus atau mengelola dan atau dikelola. Sekolah sebagai organisasi, adanya siklus yang terbentuk melalui proses panjang berupa antisipasi terhadap permasalahan yang muncul di sekolah dan kepekaan terhadap problem yang terjadi dalam proses pelaksanaan kegiatan proses belajar mengajar di sekolah. Sebagai organisasi pembelajar, dalam prakteknya sekolah merefleksikan system thinking dan system dinamic, yaitu setiap pelaku organisasi akan memetakan siklus belajar yang tertanam dalam dirinya.

Guru sebagai salah satu komponen penggerak utama di dalam organisasi sekolah akan lebih berkembang kemampuan dan kompetensinya jika melaksanakan proses belajar. Sehingga, seorang guru telah membentuk dirinya menjadi seorang pribadi yang kritis, yang hanya dimiliki oleh seorang peneliti. Seorang guru terlatih untuk peka terhadap permasalahan yang muncul, terbiasa dengan cara berpikir sistematis dan akan lebih menjiwai peranannya sebagai guru.

Proses belajar dalam sebuah organisasi tidak akan berjalan jika kepala sekolah sebagai pimpinan tertinggi di sekolah tidak memahami perlunya proses ini. Selain itu, pemerintah daerah juga harus memberikan otonomi yang luas kepada sekolah agar pelaku dalam lembaga sekolah senantiasa bersifat kritis. Kekritisan yang dilatih dalam lembaga sekolah tidak berarti harus demonstrasi/protes guru/siswa/orang tua terhadap kebijakan sekolah/pemerintah, tetapi sifat kritis disertai analisa tajam, mengapa sebuah konsep perlu diprotes, dan yang lebih penting disertai dengan solusi yang lebih baik.

\section{Peningkatan Kompetensi Guru pada Level Kabupaten/Kota}

Adanya otonomi daerah dimana pendidikan merupakan salah satu komponen yang diserahkan pengelolaannya kepada pemerintah daerah, maka pendidikan di daerah harus dikelola dengan mempertimbangkan potensi dan karakter daerah. Sekolah dibangun dengan pertimbangan kapasitas siswa yang masuk dan kualitas guru yang memadai. Sekolah juga dibangun dengan fasilitas yang minimum sama. Kebijakan pendidikan di daerah juga harus disusun berdasarkan survey yang akurat tentang fakta di lapangan. Pelatihan/pendidikan yang perlu disiapkan untuk guru bukanlah pendidikan tentang konsep mendidik, tetapi pendidikan ilmu murni. Oleh karenanya, kerjasama dengan universitas perlu dikembangkan untuk membuat link peng-update-an keilmuan guru. Lembaga pendidikan guru adalah lembaga untuk calon guru guna mempersiapkan calon guru dengan bekal ilmu kependidikan untuk menjalankan profesinya.

Semua kegiatan tersebut tidak akan berjalan jika pemerintah setempat tidak mendukung dengan baik, dan guru juga bersemangat untuk menjadi maju. Semua guru akan hadir di forum tersebut dengan kerelaan, karena sekolah tidak pernah mewajibkan. Bahkan, rela membayar uang pendaftaran atau biaya akomodasi sendiri. Daya tarik forum ini dilihat dari tema pembicaraan dan narasumber yang akan mengisi sehingga memotivasi guru untuk hadir, jika pelaksanaanya di hari Sabtu dan Minggu memungkinkan semua guru hadir.

\section{SIMPULAN}

Berdasarkan pembahasan kajian pustaka tentang kebijakan program peningkatan kesejahteraan guru dalam rangka meningkatkan mutu pendidikan disimpulkan bahwa inti dari mutu pendidikan terletak 
pada apa yang terjadi dan berlangsung di ruang kelas. Hal ini dibuktikan dengan beberapa penelitian pendidikan yaitu salah satu faktor dominan yang menentukan tingkat keberhasilan anak didik dalam melakukan proses transformasi ilmu pengetahuan dan teknologi adalah kompetensi guru dalam melaksanakan proses pembelajaran di kelas. Oleh karena itu, masalah guru merupakan topik yang tidak habis dibahas dalam berbagai seminar, diskusi dan workshop untuk mencari berbagai alternatif pemecahan terhadap berbagai persoalan yang dihadapi guru dalam menjalankan tugasnya sebagai pengajar dan pendidik di lingkungan sekolah. Adapun masalah guru berkisar pada persoalan kurang memadainya kualifikasi akademik dan kompetensi guru, kurangnya tingkat kesejahteraan guru, distribusi guru dan kurangnya penghargaan masyarakat terhadap profesi guru. Yang paling penting harus dilakukan adalah menyiapkan sosok guru masa depan yang sesuai tuntutan reformasi pendidikan dan perkembangan ilmu pengetahuan dan teknologi.

\section{REFERENSI}

Abuddin, Nata. 2003. Manajemen Pendidikan. Jakarta: Kencana Prenada Media Group.

Amstrong, Michael. 1988. Menjadi Manajer yang Lebih Baik Lagi. Jakarta: Binarupa Aksara.

Ancok, Djamaluddin. 2001. Manajemen Sumber Daya Manusia. Yogyakarta: UGM Press.

Aria, Jalil. 1999. Pendidikan Setelah Era Orde Baru (dalam Paulia, Pannen., dkk. "Cakrawala Pendidikan "). Jakarta: Universitas Terbuka.

Arikunto, Suharsimi. 1996. Prosedur Penelitian: Suatu Pendekatan Praktek. Jakarta: Rineka Cipta.

Bernadin, H. John., Joyce, E.A. Russell. 1993. Human Resource Management, Mc Grow-Hill, inc., Singapura.

Bryson, John M. 1999. Perencanaan Strategi Organisasi Sosial. (Terjemahan M. Miftahudin). Yogyakarta: Pustaka Pelajar.

Esman, Milton, J. 1989. The Element of Institution Building. Ithaca: Cornell University Press.

Etzioni, Amitai.1969. Organisasi-organisasi Modern. (Terjemahan Suryatim). Jakarta: UI Press.

Flippo, Edwin B. 1987. Manajemen Personalia. Jakarta: Erlangga.

Gibson, Ivancevich., Donnely. 1989. Organisasi dan Manajemen. Jakarta: Erlangga.

Hadari, Nawawi. 2004. Perencanaan Strategis untuk Peningkatan Kinerja Sektor Publik. Jakarta: Gramedia Pustaka Utama.

Jackson, J.H., Morgan, CP., Paolillo, J. 1978. Organization Theory, a Macro Perspective for Management. Prentice-Hall, U.S.A.

Richardus, EI., Richardus, D. 2006. Manajemen Perguruan Tinggi Modern. Yogyakarta: Andi Offset. 